\title{
Analisis Perhitungan Prestasi Dan Efisiensi Mesin Turboprop Pesawat Cn235-100 Menggunakan Perangkat Lunak Data Reduction Program (DRP)
}

\author{
Iskandar $^{1, a)}$, Putu M Santika ${ }^{2, b),}$ Kurniadi Rasyid $^{3, c)}$ \\ 1,2,3Program Studi Teknik Mesin ITI, \\ Jl. Raya Puspiptek Serpong, Tangerang Selatan-Banten, Indonesia, 15320 \\ a) doank.iskandar@ymail.com, ${ }^{\text {b) }}$ putumsantika@yahoo.com, ${ }^{\text {c) }}$ kurniadirasyid@gmail.com
}

\begin{abstract}
Abstrak
Data Reduction Program (DRP) adalah suatu piranti lunak komputer yang berfungsi untuk menghitung prestasi, besar trim temperatur gas pada bagian antara dua turbin $(\mathrm{T} 45 \mathrm{H})$, dan efisiensi mesin pesawat terbang. DRP tidak mengalami revisi. PT. Nusantara Turbin dan Propulsi (PT. NTP) saat ini memiliki dokumen berisi rumus-rumus perhitungan DRP yang sudah berusia \pm 25 tahun. Digunakan piranti lunak DRP versi terakhir di test cell tanpa mengetahui secara rinci bagaimana proses perhitungan itu terjadi. Penelitian berupa pembandingan hasil perhitungan menggunakan rumus parameter prestasi, trim dan efisiensi yang dimiliki PT. NTP dengan hasil output DRP. Penelitian ini membuktikan bahwa rumus parameter prestasi dan trim $\mathrm{T} 45 \mathrm{H}$, mesin CT7-9C dengan lembar output hasil DRP memiliki nilai yang sesuai.
\end{abstract}

Kata kunci: Analisis DRP, rumus prestasi, rumus trim T45H, rumus efisiensi, tabel perbandingan

\begin{abstract}
Data Reduction Program (DRP) is a computer software that used to calculate the performance of the interturbine gas temperature (T45H) trim value and the efficiency of aircraft engine. DRP has not been revised for many years. PT. Nusantara Turbin Propulsi (PT. NTP) has some DRP formula documents aged \pm 25 years old. PT. NTP currently uses the latest version of DRP at the test cell without the detail of the calculation process. The research is a comparison of my calculation results of performance, T45H trim and the efficiency formulas by PT. NTP, and the DRP output results. This research shows that the performance parameters and trim T45H formulas, is compatible with DRP output sheet.
\end{abstract}

Keywords: comparison table, DRP, efficiency formula, performance formula, T45H trim formula

\section{PENDAHULUAN}

Data Reduction Program (DRP) dirancang oleh General Electric (GE) Aircraft Engines dan diberikan kepada para pelanggan untuk digunakan sebagai alat bantu pengujian prestasi mesin untuk tiap varian mesin pesawat terbang turboprop CT7. Variannya adalah mesin CT7-9C yang dipakai oleh pesawat terbang CN235-100. DRP bukanlah bagian dari mesin, melainkan program tambahan untuk fasilitas perawatan mesin. Ketika mesin diuji di test cell, beberapa parameter mesin, seperti tekanan, temperatur, putaran turbin, dll, diukur dengan menggunakan sensor. Tidak semua bagian pada mesin yang dapat diukur seperti temperatur di inlet turbin gas generator (T41), padahal parameter tersebut cukup penting yang diantaranya untuk mengetahui efisiensi mesin. Untuk mengetahui T41 tersebut, digunakanlah DRP untuk menghitungnya berdasarkan data parameter-parameter yang terukur saat pengujian. Seperti ditunjukkan pada gambar 1, data-data hasil pengukuran tekanan, temperatur, dan parameterparameter lainnya saat pengujian di test cell dimasukkan ke dalam perangkat lunak (software) DRP secara manual oleh operator.

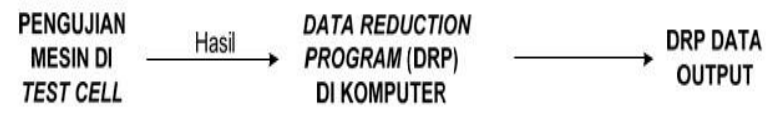

Gambar 1. Skema Kerja DRP

Dalam perkembangannya, DRP tidak lagi digunakan hanya untuk menghitung trim T45, tetapi juga menghitung parameter prestasi mesin seperti konsumsi bahan bakar spesifik (specific fuel consumption/sfc), daya mesin yang dihasilkan, dan efisiensi komponen mesin. PT. Nusantara Turbin dan Propulsi (PT. NTP), yang merupakan salah satu dari berbagai perusahaan perawatan mesin pesawat terbang di dunia, saat ini hanya memakai DRP tersebut di test cell tanpa mengetahui secara lebih rinci bagaimana proses perhitungan yang terjadi di DRP.

Sebenarnya, PT. NTP menyimpan dokumen yang berisi tentang rumus-rumus dalam proses perhitungan 
tersebut sejak \pm 25 tahun lalu. Namun mengingat usia dari software DRP tersebut, dirasa perlu untuk mengetahui seberapa besar keyakinan bahwa hasil lembar output DRP sesuai dengan hasil perhitungan rumus-rumus yang disimpan PT NTP tersebut.

Penelitian ini membandingkan berapa perbedaan antara perhitungan dengan hasil DRP, serta mengetahui perhitungan yang terjadi pada software DRP.

Makalah membatasi masalah pada Mesin yang dijadikan sampel adalah CT7-9C, Data hasil pengujian mesin adalah pada fase take-off, Data DRP yang digunakan sebagai sampel adalah ESN 309691, Data DRP yang dievaluasi hanya pada beberapa bagian saja, yakni component performance breakdown, physical engine performance, T45H margin, dan T45H trim.

Tujuan penelitian adalah untuk mengidentifikasi perbedaan hasil perhitungan parameter prestasi, trim $\mathrm{T} 45 \mathrm{H}$, dan efisiensi mesin CT7-9C dengan data output DRP.

\section{LANDASAN TEORI}

Turboprop merupakan jenis mesin pesawat terbang yang menggunakan turbin gas untuk menggerakkan propeller. Saat ini, mesin-mesin turboprop umumnya digunakan pada pesawat terbang berkecepatan rendah (subsonik). Mesin turboprop ditunjukkan pada gambar 2 .

Pada bentuk yang paling sederhana, turboprop terdiri atas intake, kompresor, ruang bakar, turbin, dan exhaust. Udara mengalir ke intake, kemudian mengalami proses kompresi oleh kompresor sehingga terjadi kenaikan tekanan dan temperatur udara. Dalam ruang bakar, bahan bakar ditambahkan pada udara terkompresi, kemudian campuran tersebut dibakar. Proses pembakaran berlangsung pada tekanan konstan, sehingga boleh dikatakan bahwa ruang bakar hanya berfungsi untuk menaikkan temperatur gas. Gas panas hasil pembakaran diekspansi melalui turbin. Sekitar $60 \%$ dari daya yang dibangkitkan oleh turbin digunakan untuk menggerakkan kompresor. Sisanya ditransmisikan melalui reduction gear untuk memutar propeller. Gas keluaran turbin keluar melalui exhaust.

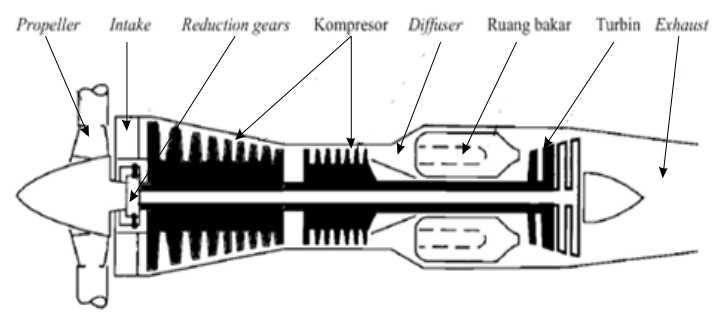

Gambar 2. Diagram Skematik Turboprop Sederhana

\section{A. Perhitungan Prestasi Mesin Ct7-9c}

Parameter yang akan dihitung nilainya adalah FHV, SHP, SHPE, SFC, SFCE, T45H Margin, TRQEDL, dan TORQUE ERROR. Formula sesuai petunjuk yang terdapat di Document PT. NTP [1] seperti yang ditunjukkan pada Rumus yang memperlihatkan perhitungan evaluasi prestasi secara berurutan hingga memperoleh nilai parameter prestasi yang tertera di lembar data output DRP.

- Nilai Pemanas Bahan Bakar, Fuel Heating Value (FHV)

$$
\mathrm{FHV}=\mathrm{LHV}+(0,475 \times[\mathrm{TWF}-519,688])
$$

- Daya Yang Terhitung di Dyno (SHP)

$$
\mathrm{SHP}=\mathrm{SHP} 1+\mathrm{SHP} 2+\mathrm{SHP} 3
$$

- Daya Yang Terhitung Di Mesin (SHPE)

$$
\mathrm{SHPE}=\frac{\mathrm{QExNp}}{5252}
$$

- Konsumsi Bahan Bakar Spesifik Yang Terhitung Di Dyno (SFC)

$$
\mathrm{SFC}=\frac{\text { Wifk }}{S H P K}
$$

- Konsumsi Bahan Bakar Spesifik Yang Terhitung Di Mesin (SFCE)

$$
\mathrm{SFCE}=\frac{\text { Wfk }}{\text { SHPEK }}
$$

- Selisih Antara T45 Rated Dan T45 Adjusted (T45 margin)

$$
\mathrm{T} 45 \text { margin }=\mathrm{T} 45 \text { rated }- \text { T45 adjusted }
$$

- Perbedaan Torsi Yang Dihitung Di Mesin Dengan Yang Dihitung Di Dyno (TRQEDL)

$$
\text { TRQEDL }=\text { QE }-\frac{\text { SHP x } 5252}{\mathbb{N p}}
$$

- Persentase Torque Error (Torque error)

$$
\text { TORQUE ERROR }=\left(\frac{Q E-\frac{\text { SHF }}{\mathbb{N} P}}{Q E}\right) \times 100 \%
$$

B. Perhitungan Trim T45h Mesin Ct7-9c

Parameter yang akan dihitung adalah PCN2, T41, T41 F, dan DEL T45H, sesuai petunjuk yang terdapat di PT. NTP [2]. Seperti yang ditunjukkan pada Rumus yang memperlihatkan perhitungan evaluasi prestasi secara berurutan hingga memperoleh nilai parameter prestasi yang tertera di lembar data output DRP. 
- Presentase Kecepatan Rotor Turbin Gas Generator (PCN2)

$$
\mathrm{PCN} 2=\frac{\mathrm{xN} 2}{44700} \times 100 \%
$$

- Temperatur Gas Di Inlet Turbin Gas

Generator Terkoreksi Terhadap Kelembaban (T41)

$$
\mathrm{T} 41=\frac{T 41 A}{1+W A R}
$$

\section{- Trim T45H (DEL T45H)}

$$
\text { DEL T45H = T45H }- \text { T45DES }
$$

\section{Perhitungan Efisiensi Mesin Ct7-9c}

Formulasi parameter efisiensi menggunakan data pada Document PT. NTP [3] sebagai acuan utama. Referensi tersebut digunakan karena istilah- istilah parameter efisiensi sistem turbin gas yang digunakan sama dengan istilah-istilah parameter efisiensi yang digunakan di DRP.

Dari lembar data output DRP dapat diamati bahwa ada tiga parameter efisiensi yang dihitung di DRP, yakni efisiensi kompresor (E3D2), efisiensi turbin gas generator (E44D41), dan efisiensi turbin daya (E49D45). Dalam perhitungan efisiensi ini, rumus diasumsikan isentropik. Efisiensi isentropik merupakan rasio kerja aktual terhadap kerja idealnya. Kerugian dari efisiensi isentropik ini adalah ketergantungannya pada besar rasio tekanan. Dengan alasan agar hasil perhitungan yang diperoleh bisa lebih akurat, formula perhitungan efisiensi isentropik dipengaruhi rasio tekanan dan efisiensi politropiknya dengan syarat menggunakan harga rasio kalor spesifik yang tepat pada temperatur rata-rata di komponen yang hendak dihitung.

- Efisiensi Isentropik Kompresor ( E3D2)

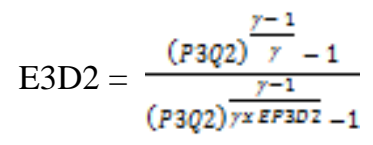

- Efisiensi Isentropik Turbin Gas Generator (E44D41)

$$
\text { E44D41 }=\frac{1-(P 41 Q 44) \frac{\text { Epsuge1 } x(1-\gamma)}{g}}{1-(P 41 Q 44) \frac{1-\gamma}{g}}
$$

- Efisiensi Isentropik Turbin Daya (E49D45)

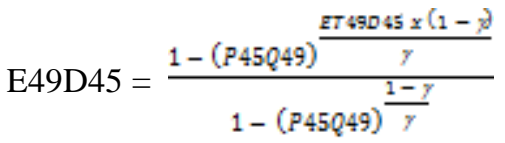

\section{METODE PENELITIAN}

Pendekatan pelaksanaan penelitian diilustrasikan dengan skema pada Gambar 3.

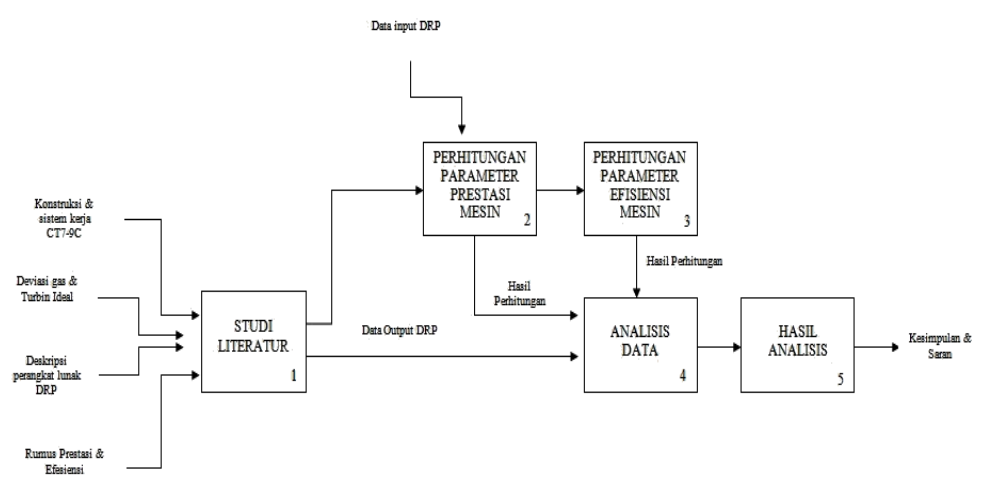

Gambar 3. Metode Penelitian

Tahap 1 - Melakukan studi literatur Pada tahap ini, dilakukan studi literatur untuk mempelajari konstruksi dan sistem kerja mesin CT7-9C yang akan diteliti. Selain itu, dipelajari juga proses pengujian mesin tersebut di test cell dan fungsi dari Data Reduction Program (DRP).

Tahap 2 - Melakukan perhitungan parameter prestasi Pada tahap ini, data-data parameter prestasi mesin kecuali parameter efisiensi dari lembar data input dihitung dengan rumus yang telah dimiliki PT. NTP. Parameter yang akan dihitung nilainya adalah FHV, SHP, SHPE, SFC, SFCE, T45H Margin, TRQEDL, dan TORQUE ERROR [1].

Tahap 3 - Melakukan perhitungan rumus efisiensi Pada tahap ini, dilakukan perhitungan rumus untuk menghitung efisiensi komponen mesin CT7-9C dengan rumus parameter efisiensi yang telah dimiliki PT. NTP [3]. Dari lembar data output DRP dapat diamati bahwa ada tiga parameter efisiensi yang dihitung di DRP, yakni efisiensi kompresor (E3D2), efisiensi turbin gas generator (E44D41), dan efisiensi turbin daya (E49D45).

Tahap 4 - Melakukan Analisis Data Pada tahap ini dilakukan analisis data antara hasil perhitungan dengan data-data dari lembar data output DRP. Dalam analisis sampel data DRP yang digunakan, $\Delta \%$ adalah prosentase selisih antara nilai hasil perhitungan DRP dengan nilai hasil perhitungan manual.

Tahap 5 - Hasil Analisis Pada tahap ini, dilakukan kesimpulan apakah perhitungan rumus-rumus parameter prestasi dan efisiensi tersebut sesuai dengan lembar hasil output pada DRP. Bila tidak sesuai, kemungkinan software DRP mengalami data program yang corrupt dan perlu dilakukan pembaruan sistem program DRP. 


\section{HASIL DAN PEMBAHASAN}

Analisis hasil perhitungan parameter prestasi, trim dan efisiensi mesin CT7-9C yang telah dihitung, dengan lembar output perangkat lunak Data Reduction Program (DRP).

\section{A. Hasil perhitungan parameter prestasi}

Tabel 1 menunjukkan perbandingan hasil perhitungan parameter prestasi mesin ESN 309691 dengan hasil perhitungan dan lembar output DRP, dengan analisis sampel data DRP yang digunakan, $\Delta \%$ adalah prosentase selisih antara nilai hasil perhitungan DRP dengan nilai hasil perhitungan manual, $\Delta$ merupakan nilai selisih antara perhitungan dan data DRP.

Pada tabel 1, terdapat beberapa perbedaan nilai hasil perhitungan dengan hasil data output DRP pada parameter prestasi ESN 309691, dimana diantaranya adalah nilai daya yang terhitung di mesin (SHPE), daya yang terhitung di dyno (SHP), selisih antara T45 rated dan T45 adjusted (T45 margin), konsumsi bahan bakar spesifik yang terhitung di mesin (SFCE), konsumsi bahan bakar spesifik yang terhitung di dyno (SFC), perbedaan torsi yang dihitung di mesin dengan yang dihitung di dyno (TRQEDL) dengan nilai selisih presentase dibawah $2 \%$. Serta didapat pula nilai hasil perhitungan dengan data output DRP yang sama nilainya, diantaranya adalah nilai fuel heating value (FHV), dan persentase torque error (Torque error) dengan nilai persentase perbedaan selisih $0 \%$. Dari analisis nilai perbandingan presentase prestasi yang di dapat antara nilai perhitungan dan hasil output DRP tidak terlalu jauh sehingga dapat disimpulkan hasil nilai perhitungan yang telah dilakukan sesuai dengan data output perangkat lunak Data Reduction Program (DRP).

Tabel 1. Perbandingan Hasil Perhitungan Prestasi ESN309691

\begin{tabular}{|l|c|c|c|c|}
\hline \multicolumn{1}{|c|}{ Besaran } & Perhitungan & DRP & $\Delta$ & $\Delta \%$ \\
\hline FHV(Fuel Heating Value) & $\begin{array}{c}18624,3 \\
\text { Btu/lb }\end{array}$ & $\begin{array}{c}18624,3 \\
\text { Btu/lb }\end{array}$ & 0 & 0 \\
\hline $\begin{array}{l}\text { SHPE(Daya Yang TerhitungDi } \\
\text { Mesin) }\end{array}$ & $1632,44 \mathrm{shp}$ & $1632,4 \mathrm{shp}$ & $-0,04$ & 0,00245 \\
\hline SHP(DayaYang TerhitungdiDyno) & $1643,26 \mathrm{shp}$ & $1643,25 \mathrm{shp}$ & $-0,01$ & 0,000609 \\
\hline $\begin{array}{l}\text { T45 margin ( Selisih Antara T45 } \\
\text { Rated Dan T45 Adjusted) }\end{array}$ & $47,3^{\circ} \mathrm{C}$ & $46,5^{\circ} \mathrm{C}$ & $-0,8$ & 1,72043 \\
\hline $\begin{array}{l}\text { SFCE(Konsumsi Bahan Bakar } \\
\text { Spesifik Yang TerhitungDiMesin) }\end{array}$ & $\begin{array}{c}0,458283 \\
\mathrm{lb} / \mathrm{hr} / \mathrm{shp}\end{array}$ & $\begin{array}{c}0,452535 \\
\mathrm{lb} / \mathrm{hr} / \mathrm{shp}\end{array}$ & $-0,005748$ & 1,270178 \\
\hline $\begin{array}{l}\text { SFC(Konsumsi Bahan Bakar } \\
\text { Spesifik Yang TerhitungDiDyno) }\end{array}$ & $\begin{array}{c}0,455266 \\
\mathrm{lb} / \mathrm{hr} / \mathrm{shp}\end{array}$ & $\begin{array}{c}0,449549 \\
1 \mathrm{~b} / \mathrm{hr} / \mathrm{shp}\end{array}$ & $-0,005717$ & 1,271719 \\
\hline $\begin{array}{l}\text { TRQEDL( Perbedaan Torsi Yang } \\
\text { Dihitung Di Mesin Dengan Yang } \\
\text { Dihitung Di Dyno) }\end{array}$ & $-2,58439 \mathrm{lb} / \mathrm{ft}$ & -2591090 \\
$\mathrm{lb} / \mathrm{ft}$ & $-0,0067$ & 0,258578 \\
\hline $\begin{array}{l}\text { Torqueerror (Persentase Torque } \\
\text { Error) }\end{array}$ & $-0,7 \%$ & $-0,7 \%$ & 0 & 0 \\
\hline
\end{tabular}

\section{B. Hasil perhitungan parameter trim $\mathrm{T} 45 \mathrm{H}$}

Pada tabel 2 menunjukkan perbandingan hasil perhitungan parameter Trim T45H mesin ESN 309691 dengan hasil perhitungan dan lembar output DRP, dengan analisis sampel data DRP yang digunakan, $\Delta \%$ adalah prosentase selisih antara nilai hasil perhitungan DRP dengan nilai hasil perhitungan manual, $\Delta$ merupakan nilai selisih antara perhitungan dan data DRP.
Tabel 2 memperlihatkan beberapa perbedaan nilai hasil perhitungan dengan hasil data output DRP pada parameter prestasi ESN 309691, dimana diantaranya adalah nilai temperatur gas di inlet turbin gas generator terkoreksi terhadap kelembaban (T41), temperatur udara di inlet turbin gas generator di kokpit (T41 F), Trim T45H (DEL T45H), dengan nilai selisih presentase dibawah $1 \%$. Serta didapat pula nilai hasil perhitungan dengan data output DRP yang sama nilainya, diantaranya adalah nilai presentase Kecepatan Rotor Turbin Gas Generator (PCN2) dengan nilai persentase perbedaan selisih 0\%. Dari analisis nilai perbandingan presentase trim $\mathrm{T} 45 \mathrm{H}$ yang di dapat antara nilai perhitungan dan hasil output DRP tidak terlalu jauh sehingga dapat disimpulkan hasil nilai perhitungan yang telah dilakukan sesuai dengan data output perangkat lunak Data Reduction Program (DRP).

Tabel 2. Perbandingan Hasil Perhitungan Trim T45H ESN 309691

\begin{tabular}{|l|c|c|c|c|}
\hline \multicolumn{1}{|c|}{ Besaran } & Perhitungan & DRP & $\Delta$ & $\Delta \%$ \\
\hline $\begin{array}{l}\text { PCN2 (Presentasekecepatan rotor } \\
\text { turbingas generator) }\end{array}$ & $98,0995 \%$ & $98,0995 \%$ & 0 & 0 \\
\hline $\begin{array}{l}\text { T41 (Temperaturgas di inlet turbin gas } \\
\text { generatorterkoreksi terhadap } \\
\text { kelembaban) }\end{array}$ & $2838,66^{\circ} \mathrm{R}$ & $2853,76^{\circ} \mathrm{R}$ & 15,1 & 0,53 \\
\hline $\begin{array}{l}\text { T41 F (Temperaturgas di inlet turbin } \\
\text { gas generatorterkoreksi terhadap } \\
\left.\text { kelembaban(Dalam satuan }^{\circ} \mathrm{F}\right) \text { ) }\end{array}$ & $2378,99^{\circ} \mathrm{F}$ & $2394,09^{\circ} \mathrm{F}$ & 15,1 & 0,63 \\
\hline DEL T45H(Trim T45H) & $2{ }^{\circ} \mathrm{C}$ & $-4,3^{\circ} \mathrm{C}$ & 6,3 & 0,6 \\
\hline
\end{tabular}

\section{Hasil perhitungan parameter efesiensi}

Tabel 3 menunjukkan perbandingan hasil perhitungan parameter Efisiensi mesin ESN 309691 dengan hasil perhitungan dan lembar output DRP, dengan analisis sampel data DRP yang digunakan, $\Delta \%$ adalah prosentase selisih antara nilai hasil perhitungan DRP dengan nilai hasil perhitungan manual, $\Delta$ merupakan nilai selisih antara perhitungan dan data DRP.

Pada tabel 3 terdapat beberapa perbedaan nilai hasil perhitungan dengan hasil data output DRP pada parameter efisinsi ESN 309691, dimana diantaranya adalah nilai Efisiensi Isentropik Kompresor (E3D2), Efisiensi Isentropik Turbin Gas Generator (E44D41), Efisiensi Isentropik Turbin Daya (E49D45) dengan nilai selisih presentase dibawah $1 \%$. Dari analisis nilai perbandingan presentase efisiensi yang di dapat antara nilai perhitungan dan hasil output DRP tidak terlalu jauh sehingga dapat disimpulkan hasil nilai perhitungan yang telah dilakukan sesuai dengan data output perangkat lunak Data Reduction Program (DRP).

Tabel 3. Perbandingan Hasil Perhitungan Efesiensi ESN 309691

\begin{tabular}{|l|c|c|c|c|}
\hline \multicolumn{1}{|c|}{ Besaran } & Perhitungan & DRP & $\Delta$ & $\Delta \%$ \\
\hline $\begin{array}{l}\text { E3D2(Efisiensi } \\
\text { Isentropik Kompresor) }\end{array}$ & 0,815116 & 0,816082 & 0,000966 & 0,118406 \\
\hline $\begin{array}{l}\text { E41D44(Efisiensi } \\
\text { Isentropik Turbin Gas } \\
\text { Generator) }\end{array}$ & 0,86251 & 0,868007 & 0,005497 & 0,633239 \\
\hline $\begin{array}{l}\text { E45D45( Efisiensi } \\
\text { Isentropik Turbin Daya) }\end{array}$ & 0,92677 & 0,925677 & $-0,001093$ & 0,118097 \\
\hline
\end{tabular}




\section{KESIMPULAN}

a. Perlu dilakukan proses perhitungan yang terjadi di DRP untuk mengetahui seberapa besar keyakinan bahwa hasil lembar output DRP sesuai dengan hasil perhitungan manual rumus-rumus yang disimpan PT NTP.

b. Rumus-rumus untuk perhitungan parameter prestasi, trim $\mathrm{T} 45 \mathrm{H}$, dan efisiensi mesin CT7-9C valid.

c. Dari analisis nilai perbandingan presentase parameter prestasi yang di dapat antara nilai perhitungan dan hasil output DRP tidak terlalu jauh yaitu dengan presentasi perbedaan di bawah $2 \%$ sehingga dapat disimpulkan hasil nilai perhitungan yang telah dilakukan sesuai dengan data output perangkat lunak Data Reduction Program (DRP).

d. Dari analisis nilai perbandingan presentase parameter trim $\mathrm{T} 45 \mathrm{H}$ yang di dapat antara nilai perhitungan dan hasil output DRP tidak terlalu jauh yaitu dengan presentasi perbedaan di bawah $1 \%$ sehingga dapat disimpulkan hasil nilai perhitungan yang telah dilakukan sesuai dengan data output perangkat lunak Data Reduction Program (DRP).

e. Dari analisis nilai perbandingan presentase parameter efisiensi yang di dapat antara nilai perhitungan dan hasil output DRP tidak terlalu jauh yaitu dengan presentasi perbedaan di bawah $1 \%$ sehingga dapat disimpulkan hasil nilai perhitungan yang telah dilakukan sesuai dengan data output perangkat lunak Data Reduction Program (DRP).

\section{REFERENSI}

[1] PT. NTP. IPTN Performance Check for CT7-9B/-9C, January 31 1989, pp 129-159.

[2] PT. NTP, IPTN CT7-9C T45H Trim, November 301986.

[3] PT. NTP, efficiency machine for CT7-9B/9C Baban V. Baliga (Lynn). Gene Schmidt (GETSCO Bandung), November 161990. 